\title{
Energy partitioning in herbage-fed dairy cows offered supplementary grain during an extended lactation
}

\author{
S. R. O. Williams, ${ }^{1}$ T. Clarke, M. C. Hannah, L. C. Marett, P. J. Moate, M. J. Auldist, and W. J. Wales \\ Future Farming Systems Research Division, Department of Primary Industries, Ellinbank, Victoria 3821, Australia
}

\section{ABSTRACT}

An experiment was conducted to quantify the changes in energy partitioning resulting from grain supplementation in herbage-fed dairy cows at 4 stages during a 670-d lactation. The experiment used 16 lactating Holstein-Friesian cows, with a control and a grain treatment being randomly allocated to 8 cows each. During 4 measurement periods (each of $4 \mathrm{~d}$ in a metabolism stall and $3 \mathrm{~d}$ in an indirect calorimeter) beginning at approximately $110,270,450$, and $560 \mathrm{~d}$ in milk (DIM), the energy balance of each cow was measured. Cows in both groups were individually offered freshly cut ryegrass pasture (Lolium hybridum L.) in periods 1 and 3 and ryegrass pasture silage and alfalfa (Medicago sativa L.) hay in periods 2 and 4 . In all periods, cows in the grain group were offered an additional 4.4 to 5.0 $\mathrm{kg}$ of dry matter of cereal grain/cow per day. Adding grain to the diet increased yields of fat and protein and tended to increase yields of milk and lactose, but did not affect milk composition. Gross energy intake (GEI) declined as lactation progressed. Adding grain to the diet decreased the percentage of GEI in feces and urine, but the extent of these reductions did not change as lactation progressed. Adding grain to the diet similarly reduced the percentage of GEI lost to heat, but again the extent of the reduction remained similar as lactation progressed. The magnitude of the increase in milk energy resulting from grain supplementation did not change with advancing lactation, but tissue energy retention was greater in the first 300 DIM compared with after 300 DIM. For herbage-based diets, $\mathrm{CH}_{4}$ emissions ranged from 6.2 to $7.6 \%$ of GEI, which corresponds to 24.0 to $25.8 \mathrm{~g}$ of $\mathrm{CH}_{4} / \mathrm{kg}$ of dry matter intake. For diets supplemented with cereal grains, $\mathrm{CH}_{4}$ emissions ranged from 6.3 to $7.3 \%$ of GEI, which corresponds to 21.6 to $25.2 \mathrm{~g}$ of $\mathrm{CH}_{4} / \mathrm{kg}$ of dry matter intake. It was concluded that, for cows producing $<24 \mathrm{~kg}$ of milk/d and consuming herbage-based diets supplemented with grain, the efficiency of utilizing the additional energy

Received May 31, 2012.

Accepted September 9, 2012.

${ }^{1}$ Corresponding author: richard.williams@dpi.vic.gov.au in the grain, as measured by the loss of energy in heat, and its partitioning to milk, did not change as lactation progressed from 110 to 560 DIM.

Key words: calorimetry, extended lactation, energy utilization, methane

\section{INTRODUCTION}

Research in southeastern Australia and New Zealand has shown that Holstein-Friesian dairy cows managed in pasture-based systems are capable of lactating for much longer than $300 \mathrm{~d}$, and that the penalties in terms of annualized production of milk fat and protein are generally less than 7\% (Auldist et al., 2007; Grainger et al., 2009a; Kolver et al., 2007). Dairy farm systems that incorporate extended lactations of 450 to $540 \mathrm{~d}$, or even longer, alleviate the need for cows to conceive during peak production when they are in negative energy balance. This can result in cost savings resulting from greater in-calf rates and fewer cows culled because they fail to conceive in time for a 12-mo calving cycle. Extended lactation systems can also allow farmers to take advantage of higher milk prices in winter and improve monthly cash flow (Borman et al., 2004). These advantages can offset the additional costs of feeding cows during winter when pasture availability is low: economic analyses have shown that extended lactation systems can match or even improve profitability compared with systems in which cows calve annually (Malcolm, 2005).

In southeastern Australia, the main source of nutrients for dairy cattle is grazed pasture, supplemented with home-grown conserved forage and an average of approximately $1,000 \mathrm{~kg}$ of DM of brought-in cereal grain or pelleted concentrates per cow per year (Doyle and Stockdale, 2011). Pasture is the majority of the diet in spring, conserved forage (pasture silage and hay) is the majority of the diet in fall, and cereal grain supplements are typically fed throughout the year. Feed costs constitute 40 to $70 \%$ of total dairy farm costs (Gilmour et al., 2010); therefore, efficient use of feeds is an important driver of farm profitability. Although efficiency of feed energy use and partitioning of energy between milk and body tissue are well described for 
standard lactations of $300 \mathrm{~d}$, they have not been well documented for herbage-fed cows undergoing extended lactations.

Auldist et al. (2011) reported that for pasture-fed cows, marginal ECM responses to cereal grain supplements were similar in the first $300 \mathrm{~d}$ of lactation and in the extended lactation phase (301 to 530 DIM). This suggests that the relative partitioning of additional energy to milk production and body tissue was not influenced by DIM. However, that experiment was not designed to measure the efficiency of energy use in the diet at different stages of lactation. In other experiments using cows fed TMR diets and housed in calorimetry chambers, Kirkland and Gordon (2001a,b) reported that stage of lactation did not influence the partitioning of additional energy to milk production up to 400 DIM. They also concluded that stage of lactation did not alter the efficiency of energy use in the diet. No detailed examination has been done on the efficiency with which supplementary feed energy is used by cows after 300 DIM, on diets typical of those available in the rain-fed dairying districts of southeastern Australia. The objective of our research was to quantify the changes in energy partitioning resulting from grain supplementation of a fresh-pasture or conserved-forage diet at 4 stages during a 670 -d lactation.

The hypotheses tested were 1) that for cows in a pasture- and forage-based dairy system, the efficiency of gross energy intake (GEI) use for lactation will continue to decrease with DIM extending to $560 \mathrm{~d}$, and 2) that the marginal efficiency of energy use from supplementary grain to support milk production will remain constant throughout an extended lactation.

\section{MATERIALS AND METHODS}

\section{Location}

The experiment was conducted at the research farm of the Department of Primary Industries located at Ellinbank, Victoria, Australia (latitude $38^{\circ} 14^{\prime}$ S, longitude $145^{\circ} 56^{\prime} \mathrm{E}$ ), in accordance with protocols approved by the Eastern Animal Ethics Committee of the Department of Primary Industries.

\section{Cows and Experimental Design}

Two treatments were used, designated the control and grain treatments. During the experimental periods, cows in the control group received no grain, whereas those in the grain group were individually offered supplementary grain twice daily at milking. These treatments were each allocated to 8 lactating HolsteinFriesian cows (including 2 heifers) that had calved in late winter (the mean calving date was August 6). The allocation was random, subject to balancing for age, milk yield in the 2 wk before the experiment commenced, and calving date, according to the method of Baird (1994).

All cows were managed for an extended lactation by delaying breeding until approximately 450 DIM. This equated to a targeted lactation length of $670 \mathrm{~d}$. Outside the experimental periods, all cows were managed as a single herd and grazed ryegrass-based pasture supplemented with cereal grain fed twice daily in the parlor at milking times. This feeding regimen reflected common practice on pasture-based dairy farms in southern Australia. When pasture was limiting, particularly during the summer and fall, additional supplements of pasture hay (approximately $6 \mathrm{~kg}$ of $\mathrm{DM} / \mathrm{cow}$ per day) and pasture silage (approximately $10 \mathrm{~kg}$ of $\mathrm{DM} / \mathrm{cow}$ per day) were offered, to achieve an estimated daily ME intake of $180 \mathrm{MJ} /$ cow. Cows had previously been trained to be penned in metabolism stalls and the calorimetry chambers. They were milked twice daily at approximately 0700 and $1500 \mathrm{~h}$.

During the lactation, four 3-wk experimental periods were used, consisting of time spent in the paddock, the metabolism stalls, and then the calorimetry chambers. At each experimental period, each cow retained her allocated treatment from period 1 . When cows entered the metabolism stalls, they were $110 \pm 12$ (mean \pm SD, period 1; spring, November), $270 \pm 12$ (period 2; fall, April), $450 \pm 14$ (period 3; spring, October), and 560 \pm 12 (period 4; fall, February) DIM. For 2 wk before the metabolism studies commenced, seasonally available forages (pasture in spring; hay and silage in fall) were offered to the cows in the paddock. Each cow then spent $4 \mathrm{~d}$ in the metabolism stalls followed by $3 \mathrm{~d}$ in the calorimetry chambers, during which time they were fed individually. The energy balance measurements were conducted over the last $6 \mathrm{~d}$ of the experimental period.

Two calorimetry chambers were available, so pairs of cows, 1 cow in the control treatment and 1 cow in the grain treatment, entered the metabolism stalls at $3-\mathrm{d}$ intervals, and progressed to the calorimetry chambers sequentially.

In periods 1 and 3, cows in the metabolism stalls and chambers were individually offered freshly cut pasture consisting of a mixture of diploid and tetraploid ryegrass hybrids between perennial ryegrass (Lolium perenne L.) and Italian ryegrass (Lolium multiflorum L.), designated Lolium hybridum. This freshly cut pasture was intended to mimic the type of pasture that cows would normally graze in spring. The pasture mixture provided approximately $150 \mathrm{MJ}$ of ME/cow per day. In periods 2 and 4, when fresh pasture was not available, both groups were offered silage made from the above 
pasture and alfalfa hay (Medicago sativa L.) to provide the same amount of ME as in periods 1 and 3. In addition to the herbage, each cow in the grain group was offered 4.4 to $5.0 \mathrm{~kg}$ of DM of cereal grain/d, which increased their ME intake to approximately $205 \mathrm{MJ}$ of $\mathrm{ME} / \mathrm{cow}$ per day. The cereal grain used during period 1 was triticale $(\times$ Triticosecale), and wheat (Triticum) was used during periods 2,3 , and 4 . Wheat was unavailable during period 1 because of a prolonged drought in Australia. Triticale ( $\times$ Triticosecale) is a hybrid of wheat (Triticum) and rye (Secale) and has nutritional characteristics similar to wheat. This is supported by the nutrient composition detailed in Table 1. Two cows were replaced before period 3 because of injury.

\section{Measurements}

Procedures for metabolism studies have been described in full by Grainger et al. (2008). Briefly, feed offered and feed refused were weighed daily. Samples of feed and refusals were oven-dried at $100^{\circ} \mathrm{C}$ to determine DM content. Total DMI and component DMI were calculated per cow. Representative samples of herbage offered and refused, and a representative sample of grain offered were collected daily and pooled over a 6-d period. Feed samples were frozen, freeze-dried, ground through a $0.5-\mathrm{mm}$ sieve, and analyzed for nutritive characteristics by near-infrared spectroscopy (as detailed in AOAC official method 989.03; AOAC, 2000) by a commercial laboratory (Dairy One Forage Laboratory, Ithaca, NY). The nutrient compositions of the feeds offered during the 4 periods of calorimetry are presented in Table 1. Each cow was weighed before and after each of the 4 energy balance studies.

Milk was weighed at each milking, and a subsample was collected for analysis of concentrations of fat, protein, and lactose using an infrared milk analyzer (model 2000; Bentley Instruments, Chaska, MN). These data were used to determine the energy content of milk (Perrin, 1958). Gross energy values of feed, feces, and urine were measured using an adiabatic calorimeter calibrated with a benzoic acid standard (Parr 1261 Isoperibol Bomb Calorimeter; Parr Instrument Co., Moline, IL).

\section{Operation of the Calorimeters}

The physical dimensions and major characteristics of the calorimeters and emissions calculations have been described previously (Grainger et al., 2007). In the current experiment, air inside the chambers was maintained at a set relative humidity (58\%) and temperature $\left(17^{\circ} \mathrm{C}\right)$.

The air streams were sequenced to the analyzer in a 12-min cycle. The intake air (common to both cham-

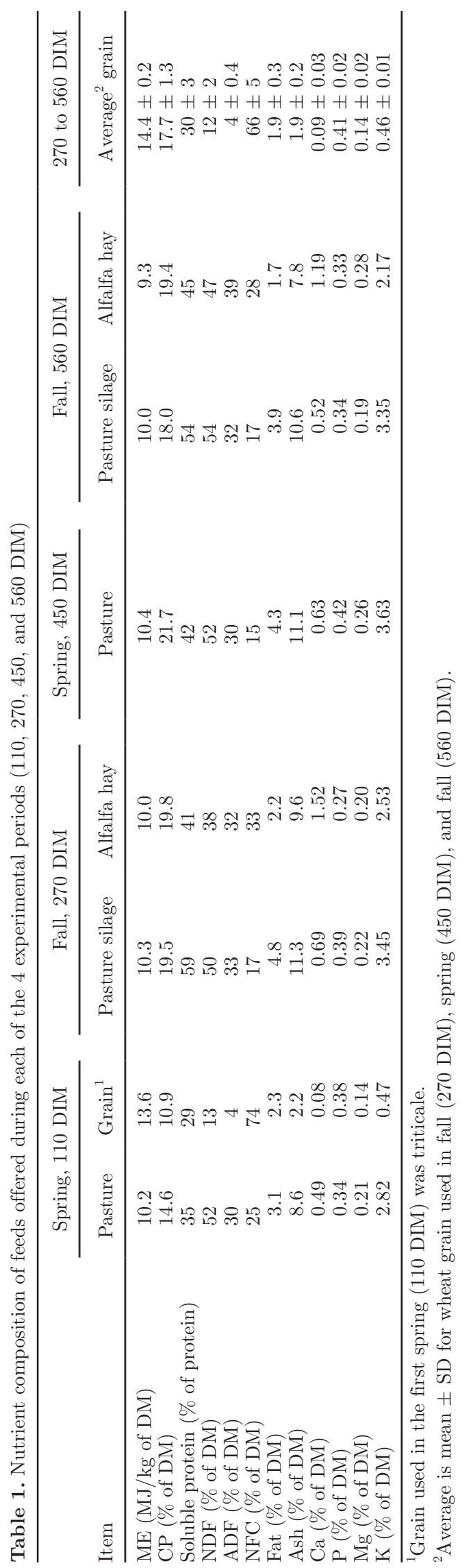


bers) was sampled for $4 \mathrm{~min}$, followed by the exhaust from chamber 1 for $4 \mathrm{~min}$ and then the exhaust from chamber 2 for the final 4 min. Sequencing of the sample streams to the analyzer was controlled by solenoids controlled by a data logger. All air streams passed through a mass-flow controller (Aalborg GFC17; Aalborg Instruments \& Controls Inc., New York, NY) set at $1.0 \mathrm{~L} / \mathrm{min}$ to ensure the instruments received a steady stream of air regardless of pump performance. A rotameter set (Aalborg PMR3-010071, Aalborg Instruments \& Controls Inc.) was used to partition the air into 2 substreams. One substream (110 units) was directed to an infrared $\mathrm{CH}_{4}$ sensor (Gfx $50 \mathrm{vpm}, 0-500 \mathrm{ppm}$; Servomex, East Sussex, UK). The other substream (10 units) was directed to an infrared $\mathrm{CO}_{2}$ sensor (IR1520 $1 \%, 0-1 \%$; Servomex), which was followed by a paramagnetic $\mathrm{O}_{2}$ sensor (Pm 1158, 0-100\%; Servomex). All gas sensors were fitted in a Xentra 4100C1 Gas Purity Analyzer (Servomex). The $\mathrm{O}_{2}, \mathrm{CO}_{2}$, and $\mathrm{CH}_{4}$ concentrations, exhaust air flow rates, relative humidity, and temperature of the exhaust air, gas pressure at the inlet and exhausts, and line voltage were recorded at 10-s intervals.

In period 1, calibration of the gas analyzer was as described by Grainger et al. (2007). For periods 2 to 4 , calibration of the gas analyzer was initiated manually between cow pairs, but the calibration progressed automatically. Atmospheric air was delivered for $4 \mathrm{~min}$, and then a standard gas mixture (designated as span gas, which contained $257 \mathrm{ppm}$ of $\mathrm{CH}_{4}, 2,908 \mathrm{ppm}$ of $\mathrm{CO}_{2}, 20.354 \% \mathrm{O}_{2}$, and the balance as $\mathrm{N}_{2}$; BOC, Sydney, New South Wales, Australia) was delivered for $8 \mathrm{~min}$. This was followed by a primary standard gas (supplied by CSIRO Atmospheric Research Division, Aspendale, Victoria, Australia) for $8 \mathrm{~min}$, and then ultrapure (99.999\%) di-nitrogen $\left(\mathrm{N}_{2}\right.$, our "zero" gas; Coregas, Yennora, New South Wales, Australia) for $16 \mathrm{~min}$. Atmospheric air was then used to bring the instruments back to normal operating range. Concentrations were recorded every $10 \mathrm{~s}$. Switching from calibration to data collection was done manually. This calibration provided an instrument correction factor for each of $\mathrm{O}_{2}, \mathrm{CO}_{2}$, and $\mathrm{CH}_{4}$.

Each chamber was calibrated at the beginning and end of the experiment, with additional calibrations between experiment cycles as scheduling permitted. Calibration consisted of injecting individual gases at controlled rates while running the regular data collection process. Carbon dioxide (99.5\%; Coregas) was injected at $4.0 \mathrm{~L} / \mathrm{min}$ and $\mathrm{CH}_{4}(99.95 \%$; Coregas) was injected at $0.35 \mathrm{~L} / \mathrm{min}$. Flow rates for both gases were controlled by individual Sierra mass flow controllers (model C100L.DD.2.0V1.SV1.PV2.V1.SO.CO with Viton seals and seat; Sierra Instruments, Monterey, CA).
Gas was injected via a tube through the outside wall approximately $1.8 \mathrm{~m}$ above floor level, into chamber 1 and then chamber 2 for approximately $4 \mathrm{~h}$ each. This calibration provided a total correction factor (chamber and instrument) for $\mathrm{CO}_{2}$ and $\mathrm{CH}_{4}$. The total factor for $\mathrm{O}_{2}$ was calculated using the total factors for $\mathrm{CO}_{2}$ and $\mathrm{CH}_{4}$, and instrument factors. Each total factor $\left(\mathrm{F}_{\text {total }}\right)$ includes a chamber-only factor $\left(\mathrm{F}_{\text {chamber }}\right)$ and instrument factor $\left(\mathrm{F}_{\text {instrument }}\right.$; Equation 1). The total factor is the flow rate recovered by the analyzer (after processing) divided by the input flow rate. The chamber-only factor should be constant for each chamber because gas recovery is dependent on the physical characteristics of the chamber. Because the calorimetry process uses the difference in gas concentrations, the instrument factor is the gas concentration measured by the instrument divided by the actual concentration:

$$
\mathrm{F}_{\text {total }}=\mathrm{F}_{\text {chamber }} \times \mathrm{F}_{\text {instrument }} \text {. }
$$

For each chamber, the chamber factor was calculated for $\mathrm{CO}_{2}$ and $\mathrm{CH}_{4}$, and then these 2 results were averaged to give the chamber factor. This chamber factor was used with the instrument factor for $\mathrm{O}_{2}$ to give the total factor for $\mathrm{O}_{2}$. In chamber 1 , the correction factor was 0.978 for $\mathrm{O}_{2}, 1.063$ for $\mathrm{CO}_{2}$, and 0.939 for $\mathrm{CH}_{4}$. In chamber 2 , the correction factors were $0.993,1.085$, and 0.962 , respectively.

\section{Statistical Analyses}

The data were analyzed using a mixed model with REML (GenStat; VSN International Ltd., Hemel Hempstead, UK). The model included factorial fixed effects for grain treatment, year (year $1, \mathrm{DIM}=1$ to 365 , or year 2 , DIM $=366$ to 670 ), and season (spring and fall) and fixed effects for parity (first or subsequent lactation) within each period. Random effect terms were specified for cows, pair within period (corresponding to sequencing of cow pairs through the metabolism stalls and calorimeters), and residual error (i.e., periods within cows). The model equation for cow $i$ in period $j$ was as follows:

$$
\begin{aligned}
y_{i j}= & \mu+\tau_{r}+\alpha_{s}+\beta_{t}+\gamma_{r s}+\lambda_{r t}+\delta_{s t} \\
& +\eta_{r s t}+\rho_{u}+C_{i}+P_{p}+E_{i j},
\end{aligned}
$$

where $\mu$ is the grand mean; $\tau_{r}$ is the main treatment effect ( $r=$ grain or no grain); $\alpha_{s}$ is the main effect of season ( $s=$ autumn, spring); $\beta_{t}$ is the main effect of year $(t$ $=$ up to 350 DIM, 350-560 DIM); $\gamma_{r s}$ is the interaction of treatment and season; $\lambda_{r t}$ is the interaction of treatment and year; $\delta_{s t}$ is the interaction of season and year; 
Table 2. Dry matter intake of feeds per cow, and BW at 110, 270, 450, and 560 DIM in different seasons (spring, fall) ${ }^{1}$

\begin{tabular}{|c|c|c|c|c|c|c|c|c|}
\hline Item & \multicolumn{4}{|c|}{ Spring } & \multicolumn{4}{|c|}{ Fall } \\
\hline Grain & 0 & $4.4 \pm 0.3$ & 0 & $5.0 \pm 0.0$ & 0 & $5.0 \pm 0.0$ & 0 & $5.0 \pm 0.0$ \\
\hline Pasture & $15.0 \pm 1.3$ & $13.2 \pm 1.3$ & $13.1 \pm 0.8$ & $11.4 \pm 1.4$ & 0 & 0 & 0 & 0 \\
\hline Pasture silage & 0 & 0 & 0 & 0 & $8.1 \pm 0.9$ & $7.8 \pm 0.8$ & $8.1 \pm 0.4$ & $7.7 \pm 0.7$ \\
\hline BW (kg) & $525 \pm 69$ & $527 \pm 43$ & $589 \pm 72$ & $583 \pm 43$ & $529 \pm 55$ & $555 \pm 42$ & $618 \pm 63$ & $630 \pm 47$ \\
\hline
\end{tabular}

${ }^{1}$ Data are means $\pm \mathrm{SD}$.

$\eta_{r s t}$ is the interaction of treatment, season, and year; $\rho_{u}$ is the effect of parity $(u=$ first or subsequent lactation for the cow); $C_{i}$ is the random effect of cow $i ; P_{p}$ is the random effect of cow pair $p$; and $E_{i j}$ is the residual error for cow $i$ in period $j$.

For each variable within each year and season, the response to grain feeding was calculated as the difference between the mean with grain minus the mean with no grain. Differences in response to grain treatment between the spring of year 1 and the spring of year 2 , and between the fall of year 1 and the fall of year 2 were tested by $t$-test contrasts using the variance-covariance matrix of the means. Graphs of residuals versus fitted values, histograms, and normal quantile plots of residuals were used to visually check the normality of distribution and constant variance. Occasional points (1.5\% of the data) with large standardized residuals were removed from the analysis. For energy balance tables (Tables 4 and 5), because of the small numbers of cows involved, $P$-values $<0.10$ were considered for significance because they indicated possible trends in the data (instead of the $P<0.05$ used elsewhere).

\section{RESULTS}

\section{Feed Intakes and BW}

The pasture offered during period 1 was harvested late in spring and was low in CP compared with that offered earlier in spring during period 3. In addition, the triticale grain offered in period 1 was lower in $\mathrm{CP}$ than that of the wheat offered in the other periods (Table 1). This meant that the calculated CP of the 2 diets offered in period 1 were lower (13.7 and $14.6 \%$ of $\mathrm{DM}$ ) than in periods 2 to 4 (ranging from 18.3 to $21.7 \%$ of DM for the 6 diets). Cows on the grain diet ate less forage in spring and fall than cows on the control diet, but total intake was greater for the cows on the grain diet (Table 2). The BW of all cows increased with time, with cows on both treatments having numerically similar BW at each experimental period (Table 2).

\section{Milk Yield and Composition}

Average daily milk yield of all cows over the entire extended lactation is shown in Figure 1 in relation to the 4 periods of investigation. The cumulative mean milk yield $( \pm \mathrm{SD})$ at 305 DIM was $6,635 \pm 799 \mathrm{~kg}$. Over all 4 periods, mean yields (kg/d) of milk (13.5 vs. 15.9, $P=0.042)$, milk fat $(0.65$ vs. $0.76, P=0.049)$ and milk protein $(0.47$ vs. $0.58, P=0.002)$ were increased in cows in the grain treatment compared with control cows. Addition of grain to the diet also tended to increase milk lactose yield (0.69 vs. $0.81, P=0.087$ ), but did not significantly affect the composition of milk (Table 3).

The response to grain was greater in the fall than in the spring for milk fat yield $(0.04 \mathrm{~kg} / \mathrm{d}$ in spring vs. 0.18 $\mathrm{kg} / \mathrm{d}$ in fall, $P=0.002)$ and fat + protein yield $(0.14$ $\mathrm{kg} / \mathrm{d}$ in spring vs. $0.31 \mathrm{~kg} / \mathrm{d}$ in fall, $P=0.015)$. The response of milk fat concentration to the addition of grain to the diet differed between spring and fall $(-0.36 \%$ in spring vs. $+0.14 \%$ in fall, $P=0.002)$. The protein

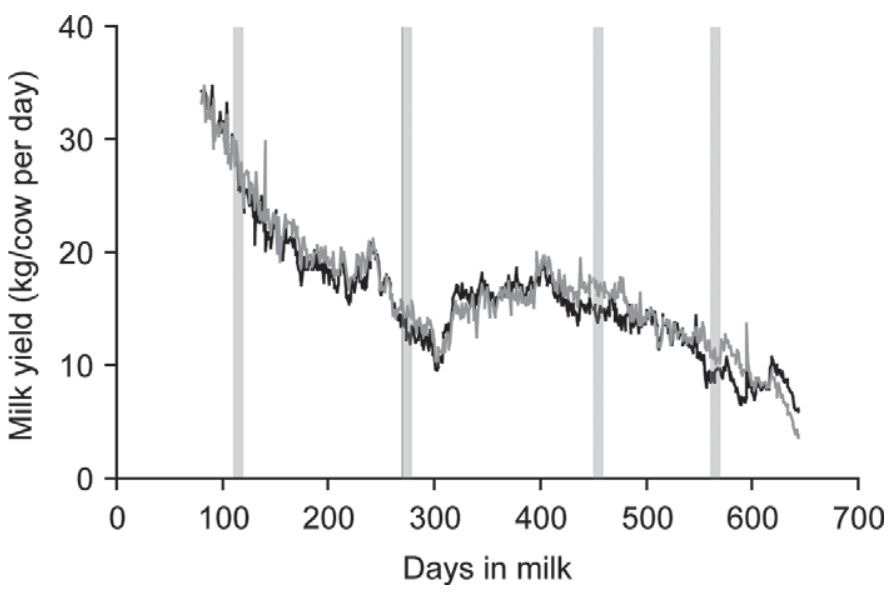

Figure 1. Average daily milk yield of cows fed no grain (black line) and cows with a grain-supplemented diet (gray line) during the experimental periods of an extended lactation. Vertical bars indicate the measurement periods. 


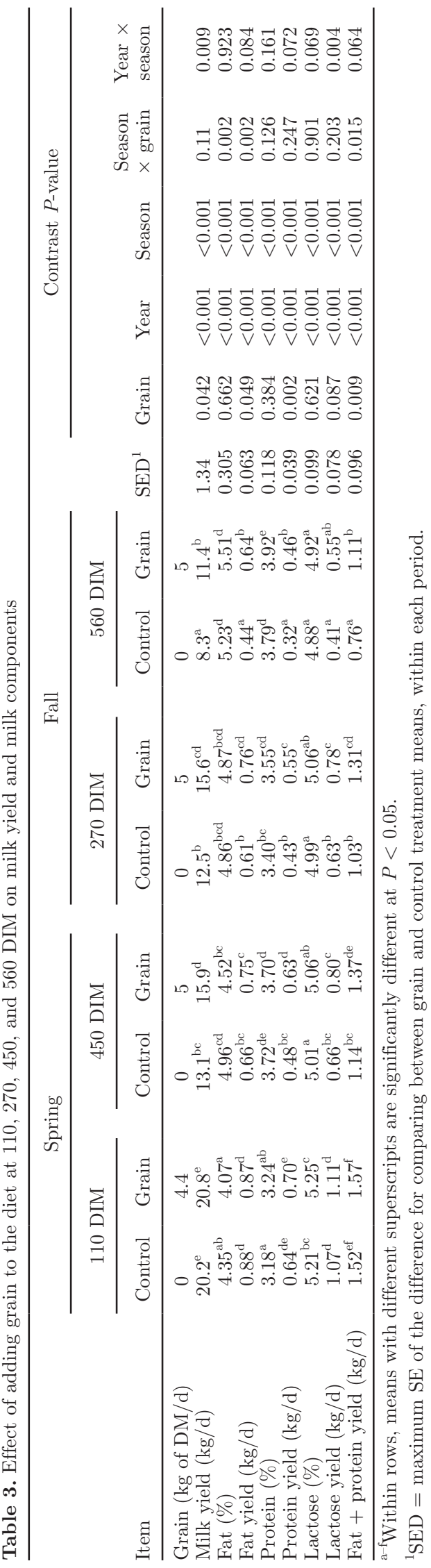

yield data were consistent with a trend of a greater response to grain in year $2(0.14 \mathrm{~kg} / \mathrm{d})$ compared with year $1(0.09 \mathrm{~kg} / \mathrm{d}, P=0.064)$. Yields of milk and milk components declined from year 1 to 2 , and declined in fall compared with spring. The concentrations of milk components, except lactose, increased from year 1 to year 2, and from spring to fall.

For all production variables, with the exception of milk protein yield $(P=0.032)$, the response to grain in the spring in year 1 was not significantly different from the response to grain in the spring in year 2. For all production variables, the responses to grain feeding in the fall of year 1 were not significantly different from the responses in the fall in year 2 .

\section{GEI, Partitioning, and Utilization of Energy}

Adding grain to the diet increased GEI (2.31 MJ/ $\mathrm{kg}$ of $\mathrm{BW}^{0.75}$ for control vs. $2.82 \mathrm{MJ} / \mathrm{kg}$ of $\mathrm{BW}^{0.75}$ for grain, $P<0.001$ ) but had no effect on fecal or urinary energy (Table 4). Methane energy was similar for all cows in spring, but in fall, $\mathrm{CH}_{4}$ energy was higher for cows fed the supplementary grain $\operatorname{diet}(0.156 \mathrm{MJ} / \mathrm{kg}$ of $\mathrm{BW}^{0.75}$ for control vs. $0.208 \mathrm{MJ} / \mathrm{kg}$ of $\mathrm{BW}^{0.75}$ for grain, $P<0.001)$. Heat $\left(0.92 \mathrm{MJ} / \mathrm{kg}\right.$ of $\mathrm{BW}^{0.75}$ for control vs. $1.06 \mathrm{MJ} / \mathrm{kg}$ of $\mathrm{BW}^{0.75}$ for grain, $\left.P=0.001\right)$, milk $(0.429$ $\mathrm{MJ} / \mathrm{kg}$ of $\mathrm{BW}^{0.75}$ for control vs. $0.503 \mathrm{MJ} / \mathrm{kg} \mathrm{BW}^{0.75}$ for grain, $P=0.030)$ and tissue energy $(0.013 \mathrm{MJ} / \mathrm{kg}$ of $\mathrm{BW}^{0.75}$ for control vs. $0.248 \mathrm{MJ} / \mathrm{kg}$ of $\mathrm{BW}^{0.75}$ for grain, $P=0.001$ ) were increased with the addition of grain to the diet. Gross energy intake was higher in year 1 compared with year 2 (2.66 for year 1 vs. 2.47 for year $2, P=0.001)$ but was similar in spring and fall. Fecal energy was lower in the spring of year 2 compared with other seasons $(P<0.001$; Table 4$)$. Urinary energy was lowest in the first spring, highest the following fall, and declined over the remaining 2 periods (Table 4). The magnitude of the increase in fecal, urinary, and $\mathrm{CH}_{4}$ energy resulting from grain supplementation of the diet did not change from year 1 to year 2 . Heat energy was similar in year 1 compared with year 2 , but was higher in spring compared with fall (spring $1.06 \mathrm{MJ} /$ $\mathrm{kg}$ of $\mathrm{BW}^{0.75}$ vs. fall $0.91 \mathrm{MJ} / \mathrm{kg}$ of $\mathrm{BW}^{0.75}, P<0.001$ ). The increase in heat energy with the addition of grain tended to be lower in spring compared with fall (0.09 $\mathrm{MJ} / \mathrm{kg}$ of $\mathrm{BW}^{0.75}$ in spring vs. $0.189 \mathrm{MJ} / \mathrm{kg}$ of $\mathrm{BW}^{0.75}$ in fall, $P=0.053)$. Milk energy was higher in year 1 than in year $2\left(0.54 \mathrm{MJ} / \mathrm{kg}\right.$ of $\mathrm{BW}^{0.75}$ in year 1 vs. 0.39 $\mathrm{MJ} / \mathrm{kg}$ of $\mathrm{BW}^{0.75}$ in year $\left.2, P<0.001\right)$ and in spring compared with fall $\left(0.55 \mathrm{MJ} / \mathrm{kg}\right.$ of $\mathrm{BW}^{0.75}$ in spring vs. $0.39 \mathrm{MJ} / \mathrm{kg}$ of $\mathrm{BW}^{0.75}$ in fall, $\left.P<0.001\right)$. The increase in milk energy with the addition of grain to the diet was lower in the first spring than in the other seasons (Table 4). Residual (tissue) energy was lower in spring 
compared with fall $\left(0.001 \mathrm{MJ} / \mathrm{kg}\right.$ of $\mathrm{BW}^{0.75}$ in spring vs. $0.260 \mathrm{MJ} / \mathrm{kg}$ of $\mathrm{BW}^{0.75}$ in fall, $\left.P<0.001\right)$.

The percentage of energy in feces was reduced by addition of grain (26.3\% for grain vs. $30.6 \%$ for control, $P<0.001)$. We had some suggestion that this loss was lower in spring compared with fall $(2.8$ vs. $6.0 \%, P=$ 0.078; Table 5), but no year $\times$ grain interaction was observed. For urine energy, a year $\times$ season $\times$ grain interaction $(P=0.014)$ was noted. The percentage of energy as urine always decreased with the addition of grain to the diet, but the decrease varied from 0.2 to $2.0 \%$ of GEI, and the reduction was not statistically significant in the spring of year 1 or fall of year 2 (Table 5 ). Adding grain to the diet in spring reduced the percentage of energy lost as $\mathrm{CH}_{4}$ by $0.9 \%$, but when grain was added in fall, it increased the percentage of energy lost as $\mathrm{CH}_{4}$ by $0.6 \%(P<0.001)$. The percentage of energy lost as heat was lower in year 1 compared with year 2 (37.4 vs. $40.6 \%, P=0.004)$. Adding grain to the diet decreased the percentage of energy lost as heat in spring by $5.5 \%(P<0.001)$, but no difference was observed in fall. The percentage of energy retained as milk in spring was higher compared with fall (21.6 vs. $14.6 \%, P<0.001)$. Adding grain to the diet decreased the percentage of energy retained in milk by $2.6 \%$ in spring compared with an increase of $0.6 \%$ in fall $(P$ $=0.003)$. For tissue energy, adding grain to the diet increased the percentage of energy retained by a higher amount in year 1 compared with year 2 (12.9 vs. $6.3 \%$, $P=0.038)$ and by a higher amount in spring compared with fall (12.9 vs. $6.3 \%, P=0.035)$.

For all energy-partitioning variables, the response to grain in the spring of year 1 was not significantly different from the response to grain in the spring of year 2. Similarly, with the exception of percentage of GEI partitioned to urine $(P=0.012)$, the energy-partitioning responses to grain feeding in the fall of year 1 were not significantly different from the responses in the fall of year 2 .

\section{DISCUSSION}

This is the first Australian research in which the energy balance of cows receiving supplementary grain at different stages of an extended lactation up to 560 DIM has been measured. In the current research, as would be expected with a spring-calving herd grazing pasture, milk yields of cows peaked in the spring of year 1 at a time when pasture quality (DM digestibility $>750 \mathrm{~g} / \mathrm{kg}$ of DM and CP $>180 \mathrm{~g} / \mathrm{kg}$ of DM) and quantity available for grazing were not limiting (Figure $1)$. Thereafter, during the summer and fall, when pasture quantity and quality became limiting, milk yields declined despite the provision of supplementary pasture silage and alfalfa hay. However, in the spring of year 2

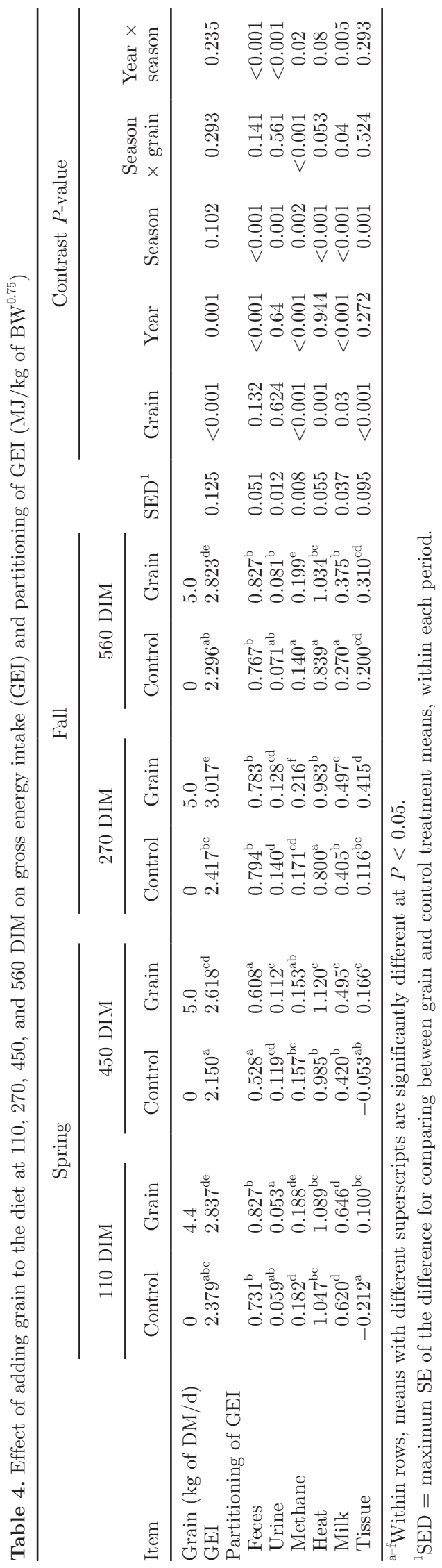


(450 DIM), a secondary peak in milk yield occurred, probably because pasture quantity and quality were again nonlimiting. Thereafter, a persistent decline in milk yield occurred.

The principal hypothesis of this research was that the efficiency of GEI use for lactation by cows in a pastureand herbage-based dairy system would decrease with DIM extending to $560 \mathrm{~d}$. We recognize, however, that a degree of confounding makes it difficult to isolate the precise cause of any observed decrease because the experiment is, by necessity, of long duration. Consequently, it is difficult to maintain a basal diet and supply of supplements that does not vary temporally in quality and composition. This is especially so in dairy systems based on grazed or harvested pasture, the quality and composition of which vary markedly as the seasons progress (Doyle and Stockdale, 2011). This is the reality in all pasture-based dairy systems, so the experiment described here sought to mimic the feeding systems present in the dairying regions of Australia. In our experiment, the best indicator of a stage-of-lactation effect on the utilization of GEI is the year effect, and the percentage utilization of GEI to heat and to milk were both significantly decreased as the extended lactation progressed. Thus, we accept our principal hypothesis.

Kirkland and Gordon, (2001a,b) also reported the energy balance of cows during an extended lactation. Our experiment is different from those of Kirkland and Gordon (2001a,b) because the ME intake of our cows was altered by increasing the amount of supplementary cereal grain offered to cows fed diets based on pasture or pasture silage and alfalfa hay, as opposed to changing the basal amounts of a TMR. Furthermore, our experiment lasted approximately $140 \mathrm{~d}$ longer than both the studies by Kirkland and Gordon (2001a,b), the longest of which lasted until 423 DIM (compared with 560 DIM in our experiment).

In our experiment, grain significantly affected the utilization of GEI for feces, urine, heat, and tissue. Adding grain to the diet increased GEI by a similar amount at the 4 stages of lactation, but GEI declined by approximately $8 \%$ from year 1 to 2 . This is consistent with the results of Auldist et al. (2011) and Kirkland and Gordon (2001a,b), who measured a decline in DMI as lactation progressed.

The second hypothesis of this research was that the marginal efficiency of use of energy from supplementary grain for supporting milk production would remain constant throughout an extended lactation. An indicator of the effect of stage of lactation on the marginal efficiency of energy utilization is the year $x$ grain interaction term because this indicates whether the efficiency of energy utilization from grain changed 
from year 1 to year 2 (i.e., as lactation progressed). In this regard, the year $\times$ grain interaction (see Table 4 ) was not significant $(P=0.191)$, indicating that the marginal efficiency of energy use from supplementary grain to support milk production did not change as the lactation progressed. Further, for all energy variables, including the percentage of GEI retained in milk, the response to grain in the spring in the second year was not significantly different from the response to grain in the spring of the first year. Similarly, with the exception of percentage of GEI partitioned to urine, the responses to grain feeding in the fall of year 1 were not significantly different from the responses in the fall of year 2. Thus, we accept the second hypothesis.

It could be suggested that the confounding changes in feed characteristics with DIM precluded us from accepting this hypothesis. However, we argue that if differences in nutrient composition of the diets in the 2 spring seasons had an effect on energy-partitioning responses in the same direction as any effect from DIM, then we are justified in concluding that DIM had no significant effect on energy partitioning. If, on the other hand, differences in nutrient composition of the diets in the 2 spring seasons had an effect on energy-partitioning responses in the opposite direction as any effect from DIM, then we can conclude that the effect attributable to DIM must have been of sufficiently small magnitude as to be cancelled out by the vagaries of changes in nutrient composition of pasture that occur from year to year. Thus, from a practical point of view, any effect from 110 to 450 DIM on energy partitioning must be small.

Adding grain to the diet decreased the percentage of GEI in feces and urine. A measure of the efficiency of energy use is indicated by heat production energy. In the current experiment, adding grain to the diet reduced the percentage of GEI to heat, but the reduction was similar in year 1 and year 2 . This is in accordance with the findings of Kirkland and Gordon (2001a,b), who reported that changes in ME intake did not alter the partitioning to heat energy at different stages of an extended lactation.

The magnitude of the increase in milk energy resulting from grain supplementation of the diet did not change from year 1 to year 2 . This is consistent with the findings of Kirkland and Gordon (2001b). In contrast, Kirkland and Gordon (2001a) reported a decline in energy partitioned to milk as the lactation progressed, regardless of whether ME intake was increased or decreased. In the latter experiment, the average milk yields of the cows at the 3 stages of lactation $(77,225$, and 423 DIM) were $40.7,28.4$, and $17.3 \mathrm{~kg}$ of milk/cow per day, respectively. In the experiment by Kirkland and Gordon (2001b), the initial milk yields of the cows were 34.3 and $18.3 \mathrm{~kg} /$ cow per day at 158 and 414 DIM, whereas in our experiment, milk yields were only $21 \mathrm{~kg} /$ cow per day at 110 DIM and they declined at subsequent stages of lactation. The greater partitioning to milk energy observed by Kirkland and Gordon (2001a), particularly in early lactation (77 DIM), may be explained by the higher initial milk yield in their experiment $(40.7 \mathrm{~kg} /$ cow per day) because the initial milk yield of the cows is an important factor in explaining higher responses in milk to changes in feeding levels (Broster et al., 1981; Grainger, 1990). It is also possible that potential differences in the genetic merit of the cows used in the 2 studies was a factor contributing to the differences in energy partitioning to milk. The current data are in accordance with the experiment by Auldist et al. (2011), in which no differences were observed in marginal milk responses to additional grain in the first $300 \mathrm{~d}$ of lactation (at 60 and 240 DIM) or in the extended-lactation phase (420 and 530 DIM). In that experiment, initial milk yields (before grain supplementation commenced) ranged from $24 \mathrm{~kg} / \mathrm{cow}$ per day at 60 DIM to $7 \mathrm{~kg} / \mathrm{cow}$ per day at 530 DIM.

When grain was added to the diet in the current experiment, it resulted in greater tissue energy retention, as a percentage of GEI, in year 1 compared with year 2 . However, when tissue energy retention was expressed as megajoules per kilogram of metabolic BW, no difference between years was observed in energy retention as tissue in response to grain. Although this is in contrast with the findings of Kirkland and Gordon (2001a,b), it may be due to differences in growth rates or body condition gain from one year to the next as cows, especially the heifers, reached their mature body size.

Added grain in the diet did not increase the amount of energy partitioned to $\mathrm{CH}_{4}$ in the spring, but it did in the fall. Expressed as a percentage of GEI, $\mathrm{CH}_{4}$ decreased by $1.2 \%$ in the spring in response to grain supplementation, but increased by $0.5 \%$ in the fall. Although the basal herbage was different in the spring and fall, it is unclear why this happened because differences in the chemical composition (DM basis) of the diets between the 2 seasons were small (NDF, 52 vs. $48 \%$; $\mathrm{ADF}, 30$ vs. $34 \%$; NFC, 20 vs. $23 \%$; CP, 18 vs. $19 \%$; fat, 2.6 vs. $3.0 \%$ ). It may have been related to a difference between the overall rumen passage rates between spring and autumn. In spring, the major component of the diet was pasture, which has a shorter rumen residence time compared with pasture silage, alfalfa hay, and grain. We speculate that when small amounts of grain are fed, these become trapped within the forage component of the diet and assume a similar rumen residence time.

Limited, and divergent, reports have been made on the magnitude of $\mathrm{CH}_{4}$ emissions when cows' diets have 
been entirely based on harvested pasture or a mix of other forages (e.g., Grainger et al., 1985, 2007, 2009b; Bruinenberg et al., 2002; O'Neill et al., 2011). Grainger et al. (1985) reported that for cows in either the second or seventh month of lactation fed entirely on harvested pasture of predominantly perennial ryegrass $(L$. perenne L.) and white clover (Trifolium repens L.), $\mathrm{CH}_{4}$ emissions ranged from 6.0 to $7.2 \%$ of GEI. Bruinenberg et al. (2002) reported that $\mathrm{CH}_{4}$ emissions averaged $6.0 \%$ of GEI for lactating cows from 24 to 306 DIM, all fed on harvested pasture. O'Neill et al. (2011) reported methane emissions of $5.74 \%$ of GEI for cows grazing grass. In the experiment reported here, lactating cows ranged from 110 to 560 DIM, and all were fed on either harvested spring pasture or a mix of pasture silage and alfalfa hay with and without a grain supplement. Methane emissions measured in our experiment were similar to those of Grainger et al. (1985) and Bruinenberg et al. (2002), ranging from 6.2 to $7.6 \%$ of GEI, which corresponds to 24.0 to $25.8 \mathrm{~g}$ of $\mathrm{CH}_{4} / \mathrm{kg}$ of DMI. Of particular importance was that when spring pasture constituted the entire diet, $\mathrm{CH}_{4}$ emissions were $7.1 \%$ of GEI or $24.6 \mathrm{~g}$ of $\mathrm{CH}_{4} / \mathrm{kg}$ of DMI, but when the spring pasture diet was supplemented with cereal grain, $\mathrm{CH}_{4}$ emissions from the total diet were reduced to $6.5 \%$ of GEI or $21.5 \mathrm{~g}$ of $\mathrm{CH}_{4} / \mathrm{kg}$ of DMI. In contrast, in the fall when the basal diet was composed of a mix of pasture silage and alfalfa hay, $\mathrm{CH}_{4}$ emissions were $6.6 \%$ of GEI or $23.7 \mathrm{~g}$ of $\mathrm{CH}_{4} / \mathrm{kg}$ of DMI, whereas when grain was fed, $\mathrm{CH}_{4}$ emissions from the total diet were increased to $7.2 \%$ of GEI or $25.2 \mathrm{~g}$ of $\mathrm{CH}_{4} / \mathrm{kg}$ of DMI. These findings suggest that $\mathrm{CH}_{4}$ emissions cannot simply be calculated from the sum of the amounts of forage and cereal grains in diets multiplied by fixed coefficients for each of these ingredients.

A focus of this research has been to examine the partitioning of GEI between milk production and energy deposition in tissue from 110 to 560 DIM. As can be seen in Table 4, within treatments, the energy excreted in milk generally decreased with DIM as milk yield declined, with the exception associated with the secondary peak in milk yield during the spring of year 2. Over the same period, the energy retained in tissues generally increased with DIM. An increase in retained energy with DIM is expected as cows replace energy stores mobilized in early lactation.

\section{CONCLUSIONS}

This research has shown that the efficiency of feed energy utilization, as measured by the loss of energy in heat, does not change when cows move into their extended lactation phase. This is the first time it has been shown for herbage-based diets. For cows produc- ing $<24 \mathrm{~kg}$ of milk/d and consuming herbage-based diets supplemented with grain, the efficiency of utilizing the additional energy in the grain, as measured by the loss of energy in heat, and its partitioning to milk, did not change as the lactation progressed from 110 to 560 DIM. The implication of our research is that dairy farmers can have confidence that pasture-based dairy systems using extended lactations can be as energy efficient as traditional systems based on the 365-d intercalving interval.

\section{ACKNOWLEDGMENTS}

The authors are grateful for the contribution of Chris Grainger (Department of Primary Industries-Victoria, Ellinbank, Australia) to the initial establishment of the work and valuable input to this manuscript. We also thank Di Mapleson, Ian Robinson, Tony Hookey, Greg Morris, Ros Case, and farm staff (Department of Primary Industries, Ellinbank, Australia) for cow husbandry and sampling. This work was financially supported by the Geoffrey Gardiner Foundation (Melbourne, Victoria, Australia), the University of Melbourne (Australia), the National Herd Improvement Association (Werribee, Victoria, Australia), the Department of Primary Industries-Victoria, Dairy Australia, Meat and Livestock Australia, and the Australian Government Department of Agriculture, Fisheries and Forestry (Canberra City, Australian Capital Territory, Australian) under the Carbon Farming Futures Filling the Research Gap Program.

\section{REFERENCES}

AOAC International. 2000. Official Methods of Analysis. 17th ed. AOAC International, Gaithersburg, MD.

Auldist, M. J., C. Grainger, K. L. Macmillan, L. C. Marett, M. Hannah, B. J. Leury, and W. J. Wales. 2011. Feed conversion efficiency and marginal production responses of pasture-fed dairy cows offered supplementary grain during an extended lactation. Anim. Prod. Sci. 51:204-209.

Auldist, M. J., G. O'Brien, D. Cole, K. L. Macmillan, and C. Grainger. 2007. Effects of varying lactation length on milk production capacity of cows in pasture-based dairying systems. J. Dairy Sci. 90:3234-3241.

Baird, D. B. 1994. The design of experiments with covariates. PhD Thesis. University of Otago, New Zealand.

Borman, J. M., K. L. Macmillan, and J. Fahey. 2004. The potential for extended lactations in Victorian dairying: A review. Aust. J. Exp. Agric. 44:507-519.

Broster, W. H., V. J. Broster, A. J. Clements, and T. Smith. 1981. The relationship between yield of milk solids of dairy cows and response to change in plane of nutrition. J. Agric. Sci. 97:643-647.

Bruinenberg, M. H., Y. van der Honing, R. E. Agnew, T. Yan, A. M. van Vuuren, and H. Valk. 2002. Energy metabolism of dairy cows fed on grass. Livest. Prod. Sci. 75:117-128.

Doyle, P. T., and C. R. Stockdale. 2011. Dairy farm management systems: Seasonal, pasture-based, dairy cow breeds. Pages 29-37 in Encyclopedia of Dairy Sciences. Vol. 2. 2nd ed. J. W. Fuquay, P. F. Fox, and P. L. H. McSweeney, ed. Academic Press, Amsterdam, the Netherlands. 
Gilmour, D., M. Ryan, C. Swann, and D. Shambrook. 2010. Dairy Industry Farm Monitor Project: Annual Report 2009/10. Dept. Primary Industries, Melbourne, Victoria, Australia.

Grainger, C. 1990. Effect of stage of lactation and feeding level on milk yield response by stall-fed dairy cows to change in pasture intake. Aust. J. Exp. Agric. 30:495-501.

Grainger, C., M. J. Auldist, G. O'Brien, K. L. Macmillan, and C. Culley. 2009a. Effect of type of diet and energy intake on milk production of Holstein-Friesian cows with extended lactations. J. Dairy Sci. 92:1479-1492.

Grainger, C., T. Clarke, M. J. Auldist, K. A. Beauchemin, S. M. McGinn, G. C. Waghorn, and R. J. Eckard. 2009b. Potential use of Acacia mearnsii condensed tannins to reduce methane emissions and nitrogen excretion from grazing dairy cows. Can. J. Anim. Sci. 89:241-251.

Grainger, C., T. Clarke, and R. J. Eckard. 2008. Effect of whole cottonseed supplementation on energy and nitrogen partitioning and rumen function in dairy cattle on a forage and cereal diet. Aust. J. Exp. Agric. 48:860-865.

Grainger, C., T. Clarke, S. M. McGinn, M. J. Auldist, K. A. Beauchemin, M. Hannah, G. C. Waghorn, H. Clark, and R. J. Eckard 2007. Methane emissions from dairy cows measured with the sulfur hexafluoride $\left(\mathrm{SF}_{6}\right)$ tracer and chamber techniques. J. Dairy Sci. 90:2755-2766.
Grainger, C., C. W. Holmes, and Y. F. Moore. 1985. Performance of Friesian cows with high and low breeding indexes. 2. Energy and nitrogen balance experiments with lactating and non-lactating cows. Anim. Prod. 40:389-400.

Kirkland, R. M., and F. J. Gordon. 2001a. The effects of stage of lactation on the partitioning of, and response to changes in, metabolisable energy intake in lactating dairy cows. Livest. Prod. Sci. 72:213-224.

Kirkland, R. M., and F. J. Gordon. 2001b. The effects of milk yield and stage of lactation on the partitioning of nutrients in lactating dairy cows. J. Dairy Sci. 84:233-240.

Kolver, E. S., J. R. Roche, C. R. Burke, J. K. Kay, and P. W. Aspin. 2007. Extending lactation in pasture-based dairy cows: I. Genotype and diet effect on milk and reproduction. J. Dairy Sci. 90:5518-5530.

Malcolm, B. 2005. Economics of extended lactations. Aust. Farm Bus. Mgt. Netwk. J. 2:110-121.

O'Neill, B. F., M. H. Deighton, B. M. O'Loughlin, F. J. Mulligan, T. M. Boland, M. O'Donovan, and E. Lewis. 2011. Effects of a perennial ryegrass diet or total mixed ration diet offered to springcalving Holstein-Friesian dairy cows on methane emissions, dry matter intake, and milk production. J. Dairy Sci. 94:1941-1951.

Perrin, D. R. 1958. The calorific value of milk of different species. J. Dairy Res. 25:215-220. 